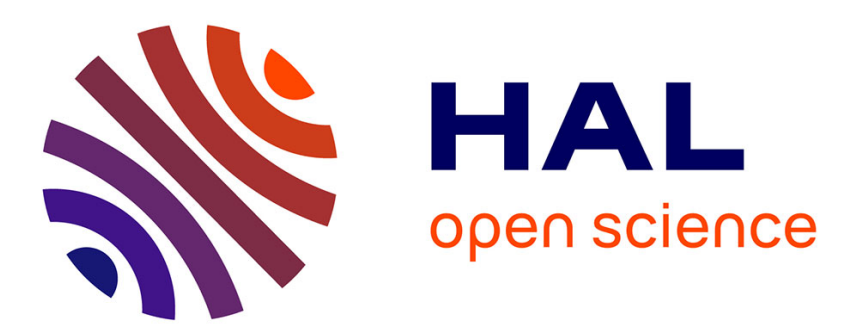

\title{
Lipid metabolism and secretory function of porcine intramuscular adipocytes compared with subcutaneous and perirenal adipocytes
}

\author{
Delphine Gardan, Florence Gondret, Isabelle Louveau
}

\section{> To cite this version:}

Delphine Gardan, Florence Gondret, Isabelle Louveau. Lipid metabolism and secretory function of porcine intramuscular adipocytes compared with subcutaneous and perirenal adipocytes. AJP - Endocrinology and Metabolism, 2006, 291, pp.E372-E380. 10.1152/ajpendo.00482.2005 . hal-02659514

\section{HAL Id: hal-02659514 \\ https://hal.inrae.fr/hal-02659514}

Submitted on 30 May 2020

HAL is a multi-disciplinary open access archive for the deposit and dissemination of scientific research documents, whether they are published or not. The documents may come from teaching and research institutions in France or abroad, or from public or private research centers.
L'archive ouverte pluridisciplinaire HAL, est destinée au dépôt et à la diffusion de documents scientifiques de niveau recherche, publiés ou non, émanant des établissements d'enseignement et de recherche français ou étrangers, des laboratoires publics ou privés. 
Delphine Gardan, Florence Gondret and Isabelle Louveau

Am J Physiol Endocrinol Metab 291:372-380, 2006. First published May 16, 2006; doi:10.1152/ajpendo.00482.2005

You might find this additional information useful...

This article cites 58 articles, 31 of which you can access free at:

http://ajpendo.physiology.org/cgi/content/full/291/2/E372\#BIBL

This article has been cited by 4 other HighWire hosted articles:

Acetyl-CoA carboxylase and stearoyl-CoA desaturase protein expression in subcutaneous adipose tissue is reduced in pigs selected for decreased backfat thickness at constant intramuscular fat content

A. Canovas, J. Estany, M. Tor, R. N. Pena and O. Doran

J Anim Sci, December 1, 2009; 87 (12): 3905-3914.

[Abstract] [Full Text] [PDF]

The origin of intermuscular adipose tissue and its pathophysiological implications

R. Vettor, G. Milan, C. Franzin, M. Sanna, P. De Coppi, R. Rizzuto and G. Federspil

Am J Physiol Endocrinol Metab, November 1, 2009; 297 (5): E987-E998.

[Abstract] [Full Text] [PDF]

Regional differences in porcine adipocytes isolated from skeletal muscle and adipose tissues as identified by a proteomic approach

F. Gondret, N. Guitton, C. Guillerm-Regost and I. Louveau

J Anim Sci, September 1, 2008; 86 (9): 2115-2125.

[Abstract] [Full Text] [PDF]

Methionine restriction effects on 11 -HSD1 activity and lipogenic/lipolytic balance in F344 rat adipose tissue

C. E. Perrone, D. A. L. Mattocks, G. Hristopoulos, J. D. Plummer, R. A. Krajcik and N. Orentreich

J. Lipid Res., January 1, 2008; 49 (1): 12-23.

[Abstract] [Full Text] [PDF]

Updated information and services including high-resolution figures, can be found at:

http://ajpendo.physiology.org/cgi/content/full/291/2/E372

Additional material and information about AJP - Endocrinology and Metabolism can be found at: http://www.the-aps.org/publications/ajpendo

This information is current as of September 2, 2010 .

AJP - Endocrinology and Metabolism publishes results of original studies about endocrine and metabolic systems on any level of organization. It is published 12 times a year (monthly) by the American Physiological Society, 9650 Rockville Pike, Bethesda MD 20814-3991. Copyright @ 2006 by the American Physiological Society. ISSN: 0193-1849, ESSN: 1522-1555. Visit our website at http://www.the-aps.org/. 


\title{
Lipid metabolism and secretory function of porcine intramuscular adipocytes compared with subcutaneous and perirenal adipocytes
}

\author{
Delphine Gardan, Florence Gondret, and Isabelle Louveau \\ Institut National de la Recherche Agronomique/Agrocampus Rennes, Unité Mixte de \\ Recherches, Systèmes d'Elevage, Nutrition Animale et Humaine, Saint Gilles, France
}

Submitted 1 December 2005; accepted in final form 6 March 2006

Gardan, Delphine, Florence Gondret, and Isabelle Louveau. Lipid metabolism and secretory function of porcine intramuscular adipocytes compared with subcutaneous and perirenal adipocytes. Am J Physiol Endocrinol Metab 291: E372-E380, 2006; doi:10.1152/ajpendo.00482.2005.-The function of adipocytes interspersed between myofiber fasciculi in skeletal muscle physiology and physiopathology is poorly documented. Because regional differences in adipocyte features have been reported in various species, we hypothesized that lipid metabolism and secretory function of intramuscular (IM) adipocytes differ from that of nonmuscular adipocytes. In the present study, adipocytes isolated from trapezius muscle were compared with subcutaneous and perirenal adipocytes in growing pigs. Between 80 and 210 days of age, gene expressions and/or activities of enzymes involved in lipogenesis or lipolysis were much lower $(P<0.05)$ in adipocytes isolated from muscle than in those from other locations. Insulin-induced lipogenesis and lipolytic efficiency after catecholamine addition were also the lowest $(P<0.05)$ in IM adipocytes. In these cells, the age-related increase $(+300 \%)$ in the ratio of mRNA levels of fatty acid synthase to hormone-sensitive lipase paralleled the enlargement of adipocyte diameters $(+70 \%, P<$ $0.05)$ and the increase in lipid content in muscle $(+135 \%, P<0.05)$ during growth. Expressions of genes coding for leptin, adiponectin, and IGF-I, as well as for various hormonal receptors, were lower $(P<$ $0.05)$ in IM adipocytes than in other adipocytes, whereas levels of TNF- $\alpha$ mRNA did not differ between sites. Interestingly, IGF-II mRNA levels were higher $(P<0.05)$ in IM adipocytes than in other adipocytes. These data support the view that IM fat is not just an ectopic extension of other fat locations but displays specific biological features during growth.

intramuscular lipids; skeletal muscle; lipogenesis; lipolysis; insulinlike growth factor II

INTRAMUSCULAR TRIACYLGLYCEROLS (TG) have recently regained special interests in both human physiology and physiopathology, and in animal production. First, TG stores serve as a major energy source for skeletal muscle during sustained exercise of moderate intensity (51). Second, an accumulation of TG within muscle has been shown to be associated with insulin resistance and related disorders (23). Third, TG content of meat is cited as an important source of dietary saturated fat, for which excess intake may be unfavorable to human health (53). Within skeletal muscle, TG are stored both intramyocellularly, as droplets in myofiber cytoplasm, and in adipocytes, interspersed between fiber fasciculi $(38,48)$. Emerging approaches, such as magnetic resonance spectroscopy, have allowed scientists to conduct several studies focused on intramyocellular TG in exercised or in insulin-resistant muscle $(23,38,56)$. On the

Address for reprint requests and other correspondence: I. Louveau, INRA/ Agrocampus Rennes, UMR Systèmes d'Elevage, Nutrition Animale et Humaine, 35590 Saint Gilles, France (e-mail: Isabelle.Louveau@rennes.inra.fr). other hand, very few studies have been devoted to intramuscular (IM) adipocytes, even though their number and size are the main determinants of TG and total lipid content variability in muscles of various species $(21,22,28)$. This paucity of information may be related to the difficulty in separating those adipocytes from adjoining myofibers.

Evidence has now accumulated to indicate that adipocytes isolated from subcutaneous (SC) or visceral adipose tissues display differences in both metabolic and secretory functions $(32,58)$. Due to their particular location in close vicinity with muscle fibers, we speculate that the biology of IM adipocytes may differ from that of adipocytes from other locations. Although sometimes controversial $(40,52)$, most of the few available data obtained from tissue explants or from isolated adipocytes are consistent with a lower lipogenic activity in IM compared with SC isolated adipocytes or adipose tissue (6, 34, 41). To our knowledge, lipolytic efficiency and secretory function of IM adipocytes remain largely unknown. Therefore, this study was undertaken to investigate anabolic and catabolic lipid metabolism and secretory function of adipocytes isolated from skeletal muscle compared with SC or perirenal adipocytes during growth. The pig was studied for its similarities to humans in terms of digestive physiology, including an omnivorous regimen, and also for its importance in meat production and meat-derived products.

\section{MATERIALS AND METHODS}

Materials. Collagenase A $(0.22 \mathrm{U} / \mathrm{mg})$ was purchased from Roche Applied Science (Meylan, France). Dulbecco's modified Eagle's medium (DMEM), HEPES, and antibiotics were obtained from Invitrogen (Cergy-Pontoise, France). The bicinchoninic acid protein assay kit was purchased from Pierce (Rockford, IL). A DNA-free kit was obtained from Ambion (Austin, TX). D-[U- $\left.{ }^{14} \mathrm{C}\right]$ glucose $(306 \mathrm{mCi} /$ $\mathrm{mmol}$ ), an ECL Western blot detection kit, Hybond C nitrocellulose membrane, random hexamer primers, and murine Moloney leukemia virus reverse transcriptase were from Amersham Biosciences (Orsay, France). Highly purified salt-free primers were generated from Proligo (Paris, France). SYBR Green I PCR core reagents and a human 18S rRNA predeveloped TaqMan kit were obtained from Applied Biosystems (Courtaboeuf, France). An EnzyPlus Glycerol kit was purchased from Diffchamb (Lyon, France). Other chemicals and reagents were supplied by Sigma (St-Quentin-Fallavier, France) or Carlo Erba (Val de Reuil, France).

Animals and sample collection. Studies were conducted in compliance with the French guidelines for human care and use of animals in research. Female Pietrain $\times($ Large White $\times$ Landrace $)$ pigs weaned at 28 days were fed ad libitum a standard diet and were killed after an overnight fast at $80(32.3 \pm 1.8 \mathrm{~kg}), 120(70.7 \pm 1.7 \mathrm{~kg}), 160$

The costs of publication of this article were defrayed in part by the payment of page charges. The article must therefore be hereby marked "advertisement" in accordance with 18 U.S.C. Section 1734 solely to indicate this fact. 
$(107.8 \pm 2.7 \mathrm{~kg}$, commercial slaughter age), or $210(147.6 \pm 3.2 \mathrm{~kg}$, age of sexual maturity) days of age ( $n=8$ per age group). Subcutaneous (SC) and perirenal adipose tissues and skeletal muscle [trapezius, composed of $\sim 48 \%$ type I oxidative, $20 \%$ type IIA oxydoglycolytic, and 3\% type IIB glycolytic myofibers (25)] were rapidly excised. Visible intermuscular adipose tissue, located in the basal lamina, was carefully removed from muscle. For adipocyte isolation, portions of tissues were placed in warm Krebs-Ringer bicarbonate buffer and processed within $30 \mathrm{~min}$. For histological analysis, samples of adipose tissue and muscle (oriented according to the longitudinal myofiber axis) were restrained on flat sticks, frozen in isopentane cooled by liquid nitrogen, and stored at $-75^{\circ} \mathrm{C}$ until analysis. For enzyme activity measurements, tissues were cut into small pieces, frozen in liquid nitrogen, and stored at $-75^{\circ} \mathrm{C}$ for later analyses.

Tissue lipid content. Total lipid content was determined in muscle, $\mathrm{SC}$, and perirenal adipose tissues after extraction with chloroformmethanol (18) and expressed as milligrams per gram of wet tissue.

Isolation of adipocytes. Adipocytes were obtained by collagenase treatment as described previously (16), with adaptations as follows. Minced tissues were shaken $(40 \mathrm{rpm})$ for $60 \mathrm{~min}$ (SC or perirenal) or for $45 \mathrm{~min}$ (muscle) at $37^{\circ} \mathrm{C}$ in sterile polypropylene flasks in Krebs-Ringer bicarbonate buffer $(3 \mathrm{ml} / \mathrm{g}$ for SC or perirenal; $2 \mathrm{ml} / \mathrm{g}$ for muscle) containing 3\% bovine serum albumin (BSA), $10 \mathrm{mM}$ glucose, $1.3 \mathrm{mg} / \mathrm{ml}$ collagenase $\mathrm{A}$, and antibiotics. The digested material was then filtered through $200-\mu \mathrm{m}$ sterile nylon mesh filters. Adipocytes isolated from SC or perirenal adipose tissues were allowed to float; they were then rinsed three times with DMEM (5.5 $\mathrm{mM}$ glucose) by removing the infranatant by means of a plastic catheter attached to a syringe. The digested material collected from muscle was first centrifuged at $100 \mathrm{~g}$ for $1 \mathrm{~min}$, and the resulting floating adipocytes were collected in DMEM at $37^{\circ} \mathrm{C}$. Adipocytes isolated from muscle in a given animal were devoted either to enzyme assays or to RNA extraction, as fewer cells were obtained compared with other fat locations. Adipocyte number in suspension was determined as previously described (36).

Determination of adipocyte diameter. An aliquot $\left(10^{3}\right.$ cells) of isolated adipocytes was digitized using a photomicroscopy system, and individual diameters $(\mu \mathrm{m})$ were measured using an image analysis system (Optimas 6.5; Media Cybernetics, Silver Spring, MD). Adipocyte diameters were also determined in five serial cross sections (10 $\mu \mathrm{m}$ thick at $40-\mu \mathrm{m}$ intervals) of frozen tissues cut with a cryostat (2800 Frigocut Reichert-Jung, Francheville, France). As previously described (21), cross sections were fixed for $10 \mathrm{~min}$ in $100 \mathrm{mM}$ phosphate buffer ( $\mathrm{pH} 7.4$ ) containing $2.5 \%$ glutaraldehyde and stained for $4 \mathrm{~min}$ in isopropanol containing $0.5 \%$ Oil Red O. A macroprogram was used to measure individual adipocyte areas by use of the image analysis system described above. Cells with a diameter below $10 \mu \mathrm{m}$ were not considered. Results corresponded to the mean of determinations performed on the five sections of each sample and were expressed as the diameter $(\mu \mathrm{m})$ of visible adipocytes. The coefficient of variation for cell diameter between the five successive sections was $3.7 \%$.

Glucose incorporation into lipids. The lipogenic rate was estimated by quantifying the conversion of $\mathrm{D}-\left[\mathrm{U}-{ }^{14} \mathrm{C}\right]$ glucose into lipids $2 \mathrm{~h}$ after cell isolation, as previously described (19). Briefly, cells $\left(\sim 2 \times 10^{5}\right.$ cells) were incubated with $14.8 \mathrm{kBq}$ of $\left[{ }^{14} \mathrm{C}\right]$ glucose at $37^{\circ} \mathrm{C}$ in the absence or presence of insulin $(17 \mathrm{nM})$ in an atmosphere of $\mathrm{O}_{2}-\mathrm{CO}_{2}$ (95:5\%). After $4 \mathrm{~h}$ of incubation, the medium was removed, and Dole's reagent was immediately added (12). After lipid extraction, incorporated radioactivity was measured by liquid scintillation counting. Preliminary experiments indicated that glucose conversion into lipids increased linearly during the incubation time. Glucose incorporation into lipids was expressed as nanomoles of glucose incorporated per $10^{5}$ cells per $4 \mathrm{~h}$.

Free glycerol release. Lipolytic rate was estimated by measuring free glycerol release in the medium $2 \mathrm{~h}$ after cell isolation, as previously described (17). Briefly, cells $\left(\sim 5 \times 10^{5}\right.$ cells $)$ were incubated at $37^{\circ} \mathrm{C}$ in $2.5 \mathrm{ml}$ of Krebs-Ringer bicarbonate buffer ( $\mathrm{pH}$ 7.4) containing $10 \mathrm{mM}$ glucose, $3 \% \mathrm{BSA}$, and $0.56 \mathrm{mM}$ ascorbic acid in the presence or absence of $10^{-5} \mathrm{M}(-)$-isoproterenol and $10^{-3} \mathrm{M}$ theophylline in an atmosphere of $\mathrm{O}_{2}-\mathrm{CO}_{2}(95: 5 \%)$. After $2 \mathrm{~h}$ of incubation, $1 \mathrm{ml}$ of the incubation medium was removed and acidified with $100 \mu \mathrm{l}$ of $30 \%$ trichloroacetic acid. The mixture was vigorously shaken and then centrifuged at $10,000 \mathrm{~g}$ for $10 \mathrm{~min}$ at $4^{\circ} \mathrm{C}$. A volume of $700 \mu \mathrm{l}$ of the supernatant was collected, neutralized with $80 \mu \mathrm{l}$ of $10 \%$ potassium hydroxide, and assayed for glycerol content according to the manufacturer's instructions. Free glycerol level was expressed as nanomoles of glycerol released per $10^{5}$ cells per $2 \mathrm{~h}$.

Enzyme assays. Isolated adipocytes $\left(2 \times 10^{6}\right.$ cells $)$ or tissue samples ( $0.6 \mathrm{~g}$ for $\mathrm{SC}$ and perirenal adipose tissues, $1.5 \mathrm{~g}$ for muscle) were homogenized in ice-cold $0.25 \mathrm{M}$ sucrose, containing $1 \mathrm{mM}$ dithiothreitol and $1 \mathrm{mM}$ EDTA. The mixtures were then centrifuged at $100,000 \mathrm{~g}$ for $1 \mathrm{~h}$ at $4^{\circ} \mathrm{C}$, and the cytosolic fraction was collected and stored at $-75^{\circ} \mathrm{C}$. Activities of enzymes representing a key step in lipogenesis [fatty acid synthase (FAS), EC 2.3.1.85] or providing a reduced equivalent for fatty acid synthesis [malic enzyme (ME), EC 1.1.1.40] were measured according to the method described by Bazin and Ferré (2). Enzyme activities were assayed spectrophotometrically at $340 \mathrm{~nm}$ absorbance following the disappearance (FAS) or the production (ME) of NADPH. Substrate quantities were optimized $(50-300 \mu \mathrm{l})$ to ensure linearity of the reactions. Protein content of the cytosolic fraction was determined using the bicinchoninic acid assay with BSA as standard. Enzyme activities were expressed as nanomoles of NADPH per minute and per milligram of proteins.

Western immunoblotting. Adipocyte cytosolic proteins $(40 \mu \mathrm{g})$ were separated on an $8 \%$ SDS-PAGE under reducing conditions and were then electrotransferred onto Hybond $\mathrm{C}$ nitrocellulose membranes. The blots were then treated as described previously (36). The FAS protein was detected with a rabbit polyclonal antibody against FAS (1:1,000; Abcam, Cambridge, UK). Autoradiograms were scanned and quantified with an image processor (Quantity One, V4, Bio-Rad, Hercules, CA).

Real-time RT-PCR. Total RNA was extracted from isolated adipocytes $\left(5 \times 10^{6}\right.$ cells) by the guanidium thiocyanate method $(7)$ with modifications (35) and then treated by DNAse. Total RNA $(3 \mu \mathrm{g})$ was reverse transcribed using random hexamer primers and murine Moloney leukemia virus reverse transcriptase according to the manufacturer's instructions. Primers for selected genes (Table 1) were designed using Primer Express software (version 2.0; Applied Biosystems, Courtaboeuf, France). Real-time quantitative PCR analyses were performed starting with $50 \mathrm{ng}$ of reverse-transcribed RNA, and both sense and antisense primers (500 $\mathrm{nM}$ for each gene, except for insulin and growth hormone receptors, $400 \mathrm{nM}$ ), in a final volume of $25 \mu \mathrm{l}$, using Sybr Green I PCR core reagents in an ABI PRISM 7000 Sequence Detection System instrument (Applied Biosystems). Forty cycles of amplification were performed, with each cycle consisting of denaturation at $95^{\circ} \mathrm{C}$ for $15 \mathrm{~s}$ and annealing and extension at $59^{\circ} \mathrm{C}$ for 1 min. Cycle threshold $\left(\mathrm{C}_{\mathrm{T}}\right)$ values are means of triplicate measurements. Absence of contamination from either genomic DNA amplification or primer dimer formation was ensured using controls without reverse transcriptase or with no DNA template and no reverse transcriptase. A melting-curve analysis was also performed, which resulted in single-product specific melting temperatures. Endogenous $18 \mathrm{~S}$ ribosomal RNA amplifications were used for each sample to normalize the expression of the selected genes. A cDNA sample of adipocytes isolated from perirenal location was used as an interplate calibrator for each gene. Because PCR efficiencies for target genes and $18 \mathrm{~S}$ gene were close to $1(1.01 \pm 0.07)$, the relative quantification for a target gene, compared with $18 \mathrm{~S}$ in a given sample in reference to the calibrator, was calculated according to the following formula (47):

$$
\text { ratio }=2^{-\Delta \mathrm{C}_{\mathrm{T}} \text { target (sample }- \text { calibrator) }} / 2^{-\Delta \mathrm{C}_{\mathrm{T}} 18 \mathrm{~S} \text { (sample }- \text { calibrator) }}
$$


Table 1. Primers used for real-time RT-PCR

\begin{tabular}{|c|c|c|c|}
\hline Gene & Accession No. & Forward Primer & Reverse Primer \\
\hline FAS & AY183428 & 5' - AGCCTAACTCCTCGCTGCAAT - 3' & $5^{\prime}-$ TCCTTGGAACCGTCTGTGTTC - 3' \\
\hline ME & X93016 & 5' - TGGTGACTGATGGAGAACGTATTC - 3' & 5'- CAGGATGACAGGCAGACATTCTT - 3' \\
\hline LPL & X62984 & $5^{\prime}-$ CCCGACGACGCAGATTTC - 3' & 5' - GGATGGCTTCCCCAATGTTA - 3' \\
\hline HSL & S80110 & 5' - CAACTTGGTGCCCACAGAAGA - 3' & 5' - GTCATGCAGTGTCAGGTACTTGAGA - 3' \\
\hline SREBP-1 & AF102873 & $5^{\prime}-$ CGGACGGCTCACAATGC - 3' & 5' - GCAAGACGGCGGATTTATTC - 3' \\
\hline $\operatorname{PPAR} \gamma$ & AF103946 & $5^{\prime}-$ ATTCCCGAGAGCTGATCCAA - 3' & $5^{\prime}$ - TGGAACCCCGAGGCTTTAT - 3' \\
\hline Insulin $\mathrm{R}$ & AF102858 & 5' - CAGCGATGTATTTCCATGTTCTGT - 3' & 5'-GCGTTTCCCTCGTACACCAT - 3' \\
\hline IGF-I R & U58370 & 5'- CAACCTCCGGCCTTTTACTTT - 3' & 5'- CAGGAATGTCATCTGCTCCTTCT - 3' \\
\hline IGF-II R & CB469268 & $5^{\prime}-$ TGCCCGGTGAAGAGCAA - 3' & $5^{\prime}-$ TTGTCCCCACACACGATAATGT - $3^{\prime}$ \\
\hline GH R & X54429 & 5' - CTGACTAGCAATGGTGGGACTGT - 3' & 5' - GTGGTTCCCATCTCACTTGGAT - 3' \\
\hline IGF-I & M31175 & 5' - GCTGGACCTGAGACCCTCTGT - 3' & 5' - TACCCTGTGGGCTTGTTGAAAT - 3' \\
\hline IGF-II & X56094 & 5' - AGGGCATCCAAACCACAAAC - 3' & 5' - GGGTTCAATTTTTGGTATGTAACTTG - 3' \\
\hline Leptin & AF102856 & 5' - GTTGAAGCCGTGCCCATCT - 3' & 5' - CTGATCCTGGTGACAATCGTCTT - 3' \\
\hline Adiponectin & AY589691 & 5' - GCTGTACTACTTCTCCTTCCACATCA- 3' & 5' - CTGGTACTGGTCGTAGGTGAAGAGT - 3' \\
\hline TNF- $\alpha$ & M29079 & $5^{\prime}-$ GGTTATCGGCCCCCAGAA - $3^{\prime}$ & $5^{\prime}-$ TGGGCGACGGGCTTATC - $3^{\prime}$ \\
\hline
\end{tabular}

FAS, fatty acid synthase; ME, malic enzyme; LPL, lipoprotein lipase; HSL, hormone-sensitive lipase; SREBP-1, sterol regulatory element-binding protein-1; PPAR $\gamma$, peroxisome proliferator-activated receptor- $\gamma$; R, receptor; IGF-I and IGF-II, insulin-like growth factor I and II; GH, growth hormone, TNF- $\alpha$, tumor necrosis factor- $\alpha$.

Statistical analyses. Data were processed by analysis of variance using the General Linear Model procedure of SAS (SAS Inst., Cary, NC). The model included the main effects of anatomic site, age, animal, and their interactions. When appropriate, an analysis of variance was realized within each site. For adipocyte diameter, the model included the main effects of the type of materials (histological cross sections or floating adipocytes), age, and their interaction. Mean values were compared using the pdiff statement of the GLM procedure (SAS). Differences were considered to be significant at $P<0.05$.

\section{RESULTS}

Lipid content in whole tissues. Whatever the age considered, lipid content in the different tissues ranked in the order: muscle $<$ SC $<$ perirenal (Table 2). It increased in all tissues between 80 and 210 days of age, but the extent of variation was higher in muscle $(+135 \%)$ than in the examined adipose tissues $(+46$ and $+35 \%$ for SC and perirenal adipose tissues, respectively).

Cellularity. Typical results for tissue cross sections and adipocyte suspension are shown in Fig. 1. Whereas diameters measured on histological cross section or isolated cells were similar for SC and perirenal adipocytes, diameters of isolated IM adipocytes were 1.3 -fold lower $(P<0.05)$ on average than those measured directly on muscle histological cross sections (data not shown). This was mainly related to a lower proportion of large adipocytes (diameter $>50 \mu \mathrm{m}$ ) and to a higher proportion of small adipocytes (diameter $<20 \mu \mathrm{m}$ ) in IM fat cell suspension compared with histological cross sections. At a given age, mean adipocyte diameters determined on histolog-

Table 2. Lipid content in muscle, SC, and perirenal adipose tissues

\begin{tabular}{lccccc}
\hline \hline \multicolumn{5}{c}{ Age (days) } & \\
\cline { 2 - 5 } & 80 & 120 & 160 & 210 & Age \\
\cline { 2 - 5 } & Effect $^{1}$ \\
\hline Muscle & $26 \pm 1^{\mathrm{a}}$ & $41 \pm 1^{\mathrm{b}}$ & $56 \pm 2^{\mathrm{c}}$ & $61 \pm 6^{\mathrm{c}}$ & $<0.001$ \\
SC & $531 \pm 17^{\mathrm{a}}$ & $630 \pm 2^{\mathrm{b}}$ & $708 \pm 13^{\mathrm{c}}$ & $773 \pm 14^{\mathrm{d}}$ & $<0.001$ \\
Perirenal & $597 \pm 34^{\mathrm{a}}$ & $724 \pm 16^{\mathrm{b}}$ & $765 \pm 16^{\mathrm{bc}}$ & $807 \pm 8^{\mathrm{c}}$ & $<0.001$ \\
\hline
\end{tabular}

Values are means $\pm \mathrm{SE}$ in $\mathrm{mg} / \mathrm{g}$ tissue; $n=8$ per group. SC, subcutaneous.

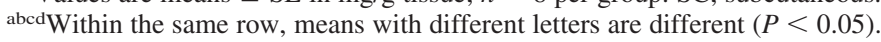
${ }^{1}$ Probability level for the effect of age within each site. ical tissue cross sections (data not shown) or on isolated adipocytes (Table 3$)$ were smaller $(P<0.001)$ in muscle than in other fat locations, whereas SC and perirenal adipocytes exhibited a similar size $(P>0.2)$. In the three sites, mean diameters of adipocytes increased with age $(P<0.05)$. Interestingly, IM adipocytes isolated from 210-day-old pigs and SC or perirenal adipocytes isolated from 80-day-old pigs exhibited similar diameters (Table 3).

Lipogenic enzymes. Whatever the age examined, specific activities of FAS and ME were lower $(P<0.05)$ in IM adipocytes than in nonmuscular adipocytes (Fig. 2). Using Western immunoblot analysis, we also detected a lower cytosolic FAS protein content in IM adipocytes than in SC and perirenal adipocytes isolated from 80-day-old pigs (Fig. 3). Relative to perirenal fat cells, isolated SC adipocytes displayed higher activities of lipogenic enzymes at 80 and 120 days of age but had similar activities thereafter. Enzyme activities did not markedly change $(P>0.2)$ with growth in IM adipocytes, whereas an age-related decrease in the activities of FAS and ME was observed in both SC $(P<0.05)$ and perirenal $(P=$ 0.07 ) adipocytes (Fig. 2). Interestingly, FAS and ME activities increased between 80 and 210 days when assessed on muscle homogenates $(P<0.05)$, whereas no significant change in enzyme activities was observed in SC and perirenal adipose tissue homogenates (data not shown).

Lipogenic and lipolytic rates. In the absence and presence of insulin, glucose incorporation into lipids was lower $(P<0.05)$ in IM adipocytes than in $\mathrm{SC}$ and perirenal adipocytes from 80-day-old pigs (Fig. 4A). SC and perirenal adipocytes displayed a similar capacity to convert glucose into lipids in both basal and insulin-stimulated conditions. Addition of insulin to the medium enhanced glucose incorporation into all adipocytes; however, this increase was lower in IM adipocytes $(+50 \%, P=0.11)$ than in SC adipocytes $(+160 \%, P<0.05)$ or perirenal adipocytes $(+280 \%, P<0.05)$. Noticeably, insulin-stimulated lipogenic rate tended to be higher $(P=0.07)$ in $\mathrm{SC}$ than in perirenal adipocytes at the latter stages of growth (data not shown). In basal and stimulated conditions, glycerol release was lower $(P<0.05)$ in IM adipocytes than in other adipocytes from 80-day-old pigs, whereas SC and perirenal adipocytes exhibited similar lipolytic rate (Fig. 4B). Addition 

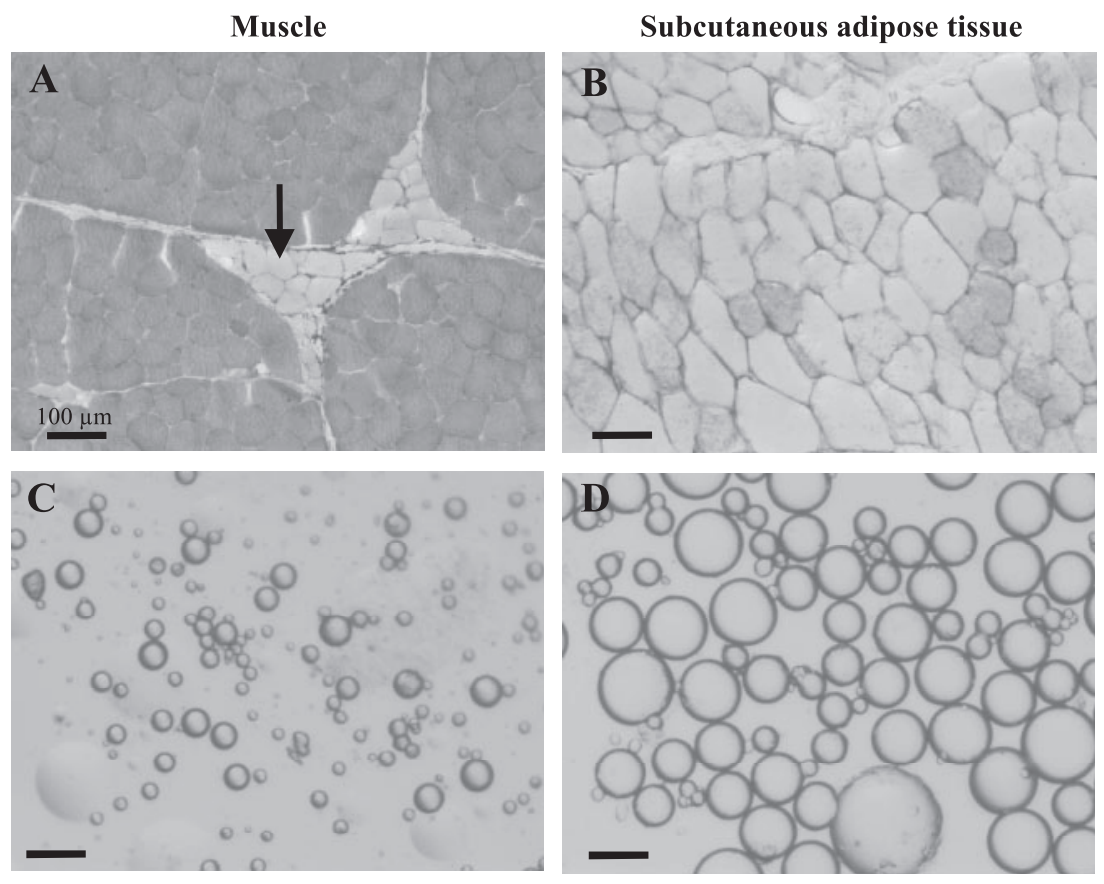

Fig. 1. Representative staining of adipocytes in trapezius muscle $(A$ and $C$ ) and in subcutaneous adipose tissue $(B$ and $D)$. Adipocytes were numerized on histological frozen cross sections after Oil Red $\mathrm{O}$ staining $(A$ and $B)$ or after isolation by collagenase treatment ( $C$ and $D$ ). Representative photos from 120-day-old pigs are shown. Adipocytes in muscle were clustered along myofiber fasciculi, as indicated by black arrow. of catecholamine to the medium enhanced glycerol release in all adipocytes; however, this increase was lower in IM adipocytes $(+20 \%, P<0.05)$ than in $\mathrm{SC}$ and perirenal adipocytes $(+110$ and $+75 \%$ respectively, $P<0.05)$.

Gene expressions. Whatever the age considered, the expressions of genes involved in lipogenesis (FAS, ME), TG hydrolysis [lipoprotein lipase (LPL), hormone-sensitive lipase (HSL)], and transcriptional regulation of lipid metabolism [sterol regulatory element-binding protein-1 (SREBP-1), peroxisome proliferator-activated receptor- $\gamma$ (PPAR $\gamma)]$ were lower $(P<0.05)$ in IM adipocytes than in SC (Fig. 5A) or perirenal (Fig. 5B) adipocytes. Expressions of genes encoding secreted factors or involved in growth and/or lipid metabolism were also assessed. Expressions of genes coding for leptin, adiponectin, IGF-I, growth hormone receptor, insulin receptor, and IGF receptors were lower $(P<0.05)$ in IM adipocytes than in SC or perirenal adipocytes, but the difference was not so pronounced compared with lipid metabolism targets. By contrast, levels of TNF- $\alpha$ mRNA did not differ $(P>0.12)$ between IM and nonmuscular adipocytes. Interestingly, levels of IGF-II mRNA differed between adipocytes $(P<0.05)$, with a higher expression in IM adipocytes than in $\mathrm{SC}$ or perirenal

Table 3. Diameters of adipocytes isolated from muscle, SC, and perirenal adipose tissues

\begin{tabular}{lccccc}
\hline \hline & \multicolumn{4}{c}{ Age (days) } & \\
\cline { 2 - 5 } & 80 & 120 & 160 & 210 & $\begin{array}{c}\text { Age } \\
\text { Effect }^{1}\end{array}$ \\
\cline { 2 - 5 } & $23 \pm 1^{\mathrm{a}}$ & $27 \pm 1^{\mathrm{ab}}$ & $33 \pm 2^{\mathrm{b}}$ & $39 \pm 3^{\mathrm{c}}$ & $<0.001$ \\
SC & $38 \pm 2^{\mathrm{a}}$ & $48 \pm 3^{\mathrm{b}}$ & $62 \pm 4^{\mathrm{c}}$ & $81 \pm 4^{\mathrm{d}}$ & $<0.001$ \\
Perirenal & $38 \pm 2^{\mathrm{a}}$ & $51 \pm 2^{\mathrm{b}}$ & $60 \pm 3^{\mathrm{c}}$ & $73 \pm 5^{\mathrm{d}}$ & $<0.001$ \\
Site effect & $<0.001$ & $<0.001$ & $<0.001$ & $<0.001$ & \\
\hline
\end{tabular}

Values are means $\pm \mathrm{SE}$ in $\mu \mathrm{m} ; n=8$ per group. IM, intramuscular.

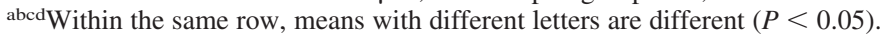
${ }^{1}$ Probability level for the effect of age within each site; ${ }^{2}$ probability level for the effect of site within each age. adipocytes, especially at 80, 120, and 160 days of age (Fig. 6). Even though some significant differences in gene expression were observed between SC and perirenal adipocytes, they were not so marked as those observed between IM and nonmuscular adipocytes (Fig. 5C). Noticeably, IGF-I and leptin mRNA levels were 1.7-fold higher in SC than in perirenal adipocytes at the latest growing stages, whereas IGF-II mRNA level was 2.3-fold higher in perirenal than in SC adipocytes at 160 days of age $(P<0.05)$. Expression of genes related to lipid metabolism in IM adipocytes did not significantly differ between age groups, with the remarkable exception of the FASto-HSL ratio, which was increased by more than $300 \%$ between 80 and 210 days of age. Leptin, adiponectin and IGF-I receptor mRNA levels increased $(P<0.05)$ with age in IM adipocytes $(+600,+200$, and $+90 \%$, respectively), whereas mRNA levels of the other studied genes coding for secreted factors or hormone receptors did not significantly change with age. In SC and perirenal adipocytes, leptin and adiponectin mRNA levels also increased $(P<0.05)$ with age (Fig. 6).

\section{DISCUSSION}

Given the clinical importance of differences in regional fat distribution (32) and the specific properties of associated adipocytes isolated from SC and visceral adipose tissues in both human and rodent models $(20,57)$, information regarding possible functional specificity of IM adipocytes could provide new insights into the control of muscle fat accumulation, body fat distribution, and/or lipid-related disorders. Therefore, we characterized adipocytes isolated from a red skeletal muscle relative to cells separated from $\mathrm{SC}$ adipose tissue (i.e., the main site of TG storage in pigs) and from a visceral adipose tissue.

We provide evidence that marked differences exist in the metabolic properties of adipocytes. Our data clearly show that IM adipocytes exhibit a much lower lipogenic activity than SC and perirenal adipocytes. Moreover, SC adipocytes tend to exhibit a higher lipogenic rate than perirenal adipocytes, in 


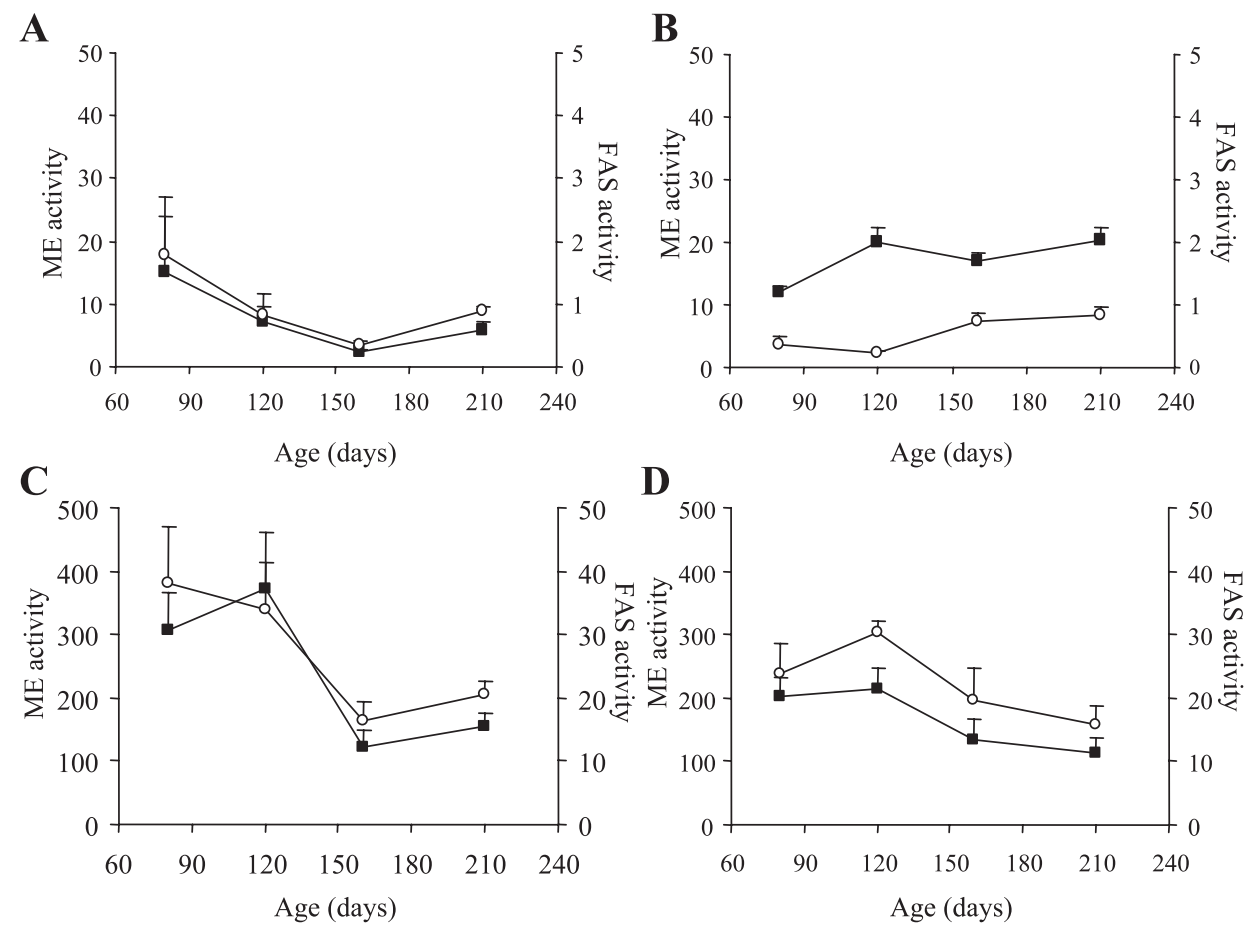

Fig. 2. Age-related changes in fatty acid synthase (FAS, $\mathrm{O}$ ) and malic enzyme (ME, specific activities measured in intramuscular (IM) adipocytes $(A)$, muscle homogenate $(B)$, and subcutaneous $(\mathrm{SC} ; C)$ and perirenal $(D)$ adipocytes. Values are means $\pm \mathrm{SE} ; n=8$ per age group for $\mathrm{SC}$ and perirenal adipocytes and muscle homogenates, $n=4$ for IM adipocytes. Activities were expressed as $\mathrm{nmol} / \mathrm{min}$ NADPH produced (ME) or oxidized (FAS) per mg proteins.

agreement with previous findings in this species $(15,36)$. On the other hand, data related to lipogenic enzyme activities in $\mathrm{SC}$ and perirenal adipocytes were largely inconsistent (current results, 1, 5, 36, 44), depending on animal age, data expression mode (cellular, protein, lipid, or tissue basis), and the enzymes considered. In humans, even though visceral adipocytes have been reported to exhibit higher rate of basal as well as insulinstimulated glucose uptake compared with SC adipocytes (37), lipogenesis is usually not considered a predominant pathway in adipose tissue compared with liver (46). The lower expressions of lipogenic parameters in IM adipocytes compared with SC and perirenal adipocytes are in agreement with previous data in cattle or pigs. Both a lower incorporation of ${ }^{14} \mathrm{C}$-labeled

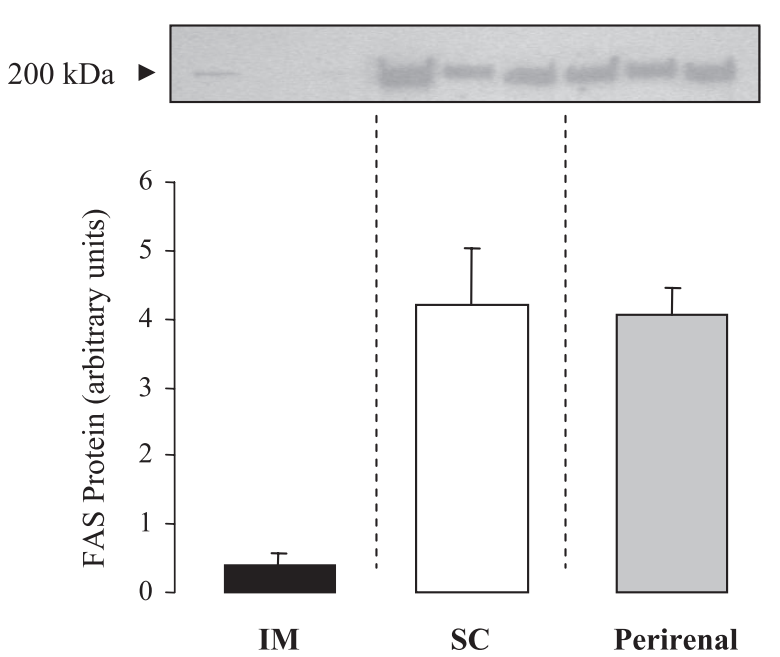

Fig. 3. FAS protein levels in IM, SC, and perirenal adipocytes from 80-dayold pigs. Proteins were detected by Western blot, as described in MATERIALS AND METHODS, and data from densitometry analyses are shown. Values are means $\pm \mathrm{SE} ; n=3$ per site.
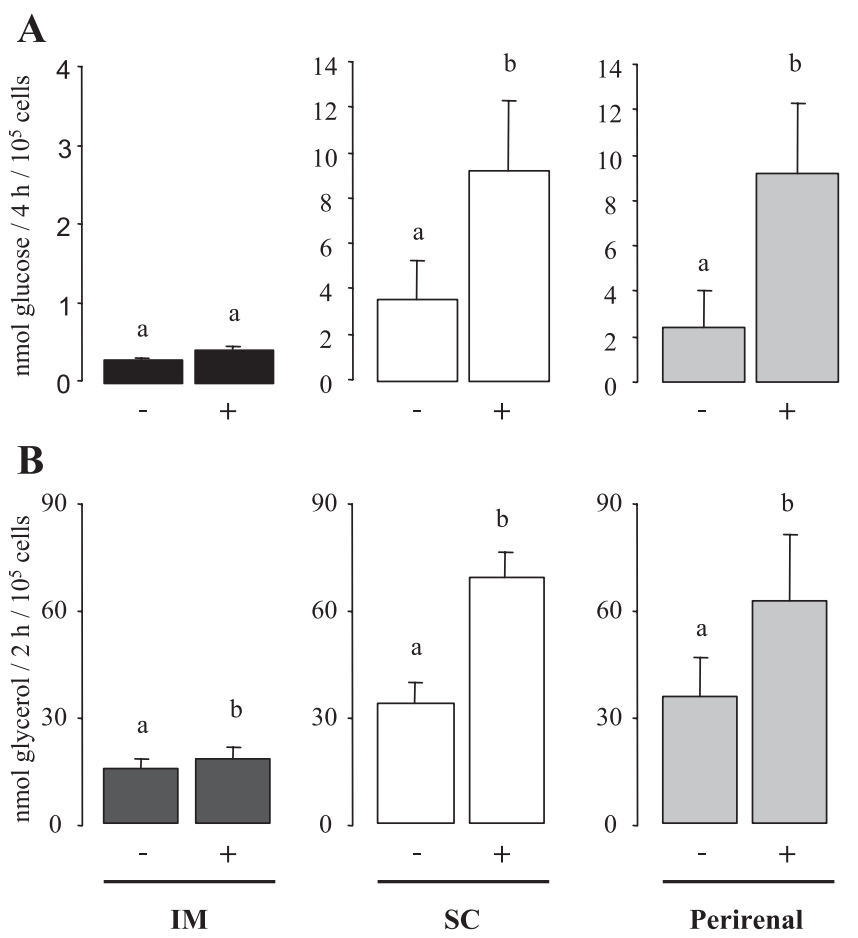

Fig. 4. Capacity of glucose incorporation $(A)$ or glycerol release $(B)$ in IM, SC, and perirenal adipocytes from 80 -day-old pigs. $\left[{ }^{14} \mathrm{C}\right]$ glucose incorporation was determined in the absence $(-)$ or presence $(+)$ of $17 \mathrm{nM}$ insulin, as described in MATERIALS AND METHODS ( $n=8$ for SC and perirenal adipocytes, $n=4$ for IM adipocytes), and expressed as nanomoles of glucose incorporated per $10^{5}$ cells per 4-h incubation. Glycerol release was determined in the absence (-) or presence (+) of $10^{-5} \mathrm{M}$ isoproterenol and $10^{-3} \mathrm{M}$ theophylline, as described in MATERIALS AND METHODS ( $n=8$ for SC and IM adipocytes, $n=$ 4 for perirenal adipocytes), and expressed as nanomoles of glycerol released per $10^{5}$ cells per 2 -h incubation. Values are means $\pm \mathrm{SE}$. ${ }^{\mathrm{ab}}$ Within each site, means with different letters are different $(P<0.05)$. 

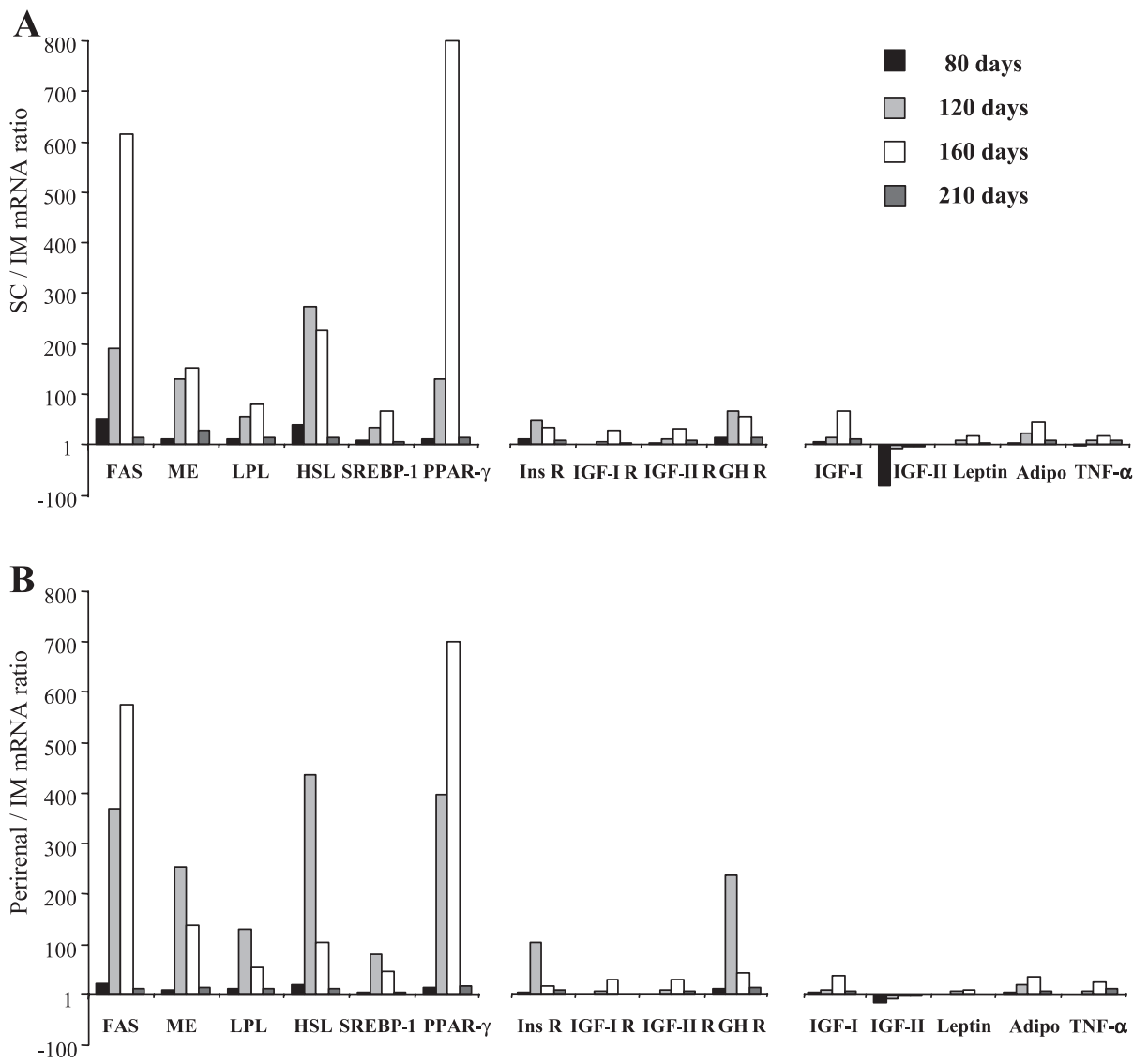

Fig. 5. Relative expression of genes in SC vs. IM $(A)$, perirenal vs. IM $(B)$, and $\mathrm{SC}$ vs. perirenal adipocytes $(C)$ in 80-, 120-, 160-, and 210-day-old pigs. Briefly, mRNA levels were quantified by real-time RT-PCR as described in MATERIALS AND METHODS $(n=8$ per age group for SC and perirenal adipocytes, $n=4$ for IM adipocytes). Data are expressed as a ratio between mean values. Ratios $<1$ are expressed as negative numbers (i.e., a ratio of 0.5 is expressed as -2). LPL, lipoprotein lipase; HSL, hormone-sensitive lipase; SREBP-1, sterol regulatory element-binding protein-1; PPAR $\gamma$, peroxisome proliferator-activated receptor- $\gamma ; \mathrm{R}$, receptor; Ins, insulin; $\mathrm{GH}$, growth hormone; IGF-I and IGF-II, insulin-like growth factor I and II; Adipo, adiponectin; TNF- $\alpha$, tumor necrosis factor- $\alpha$.

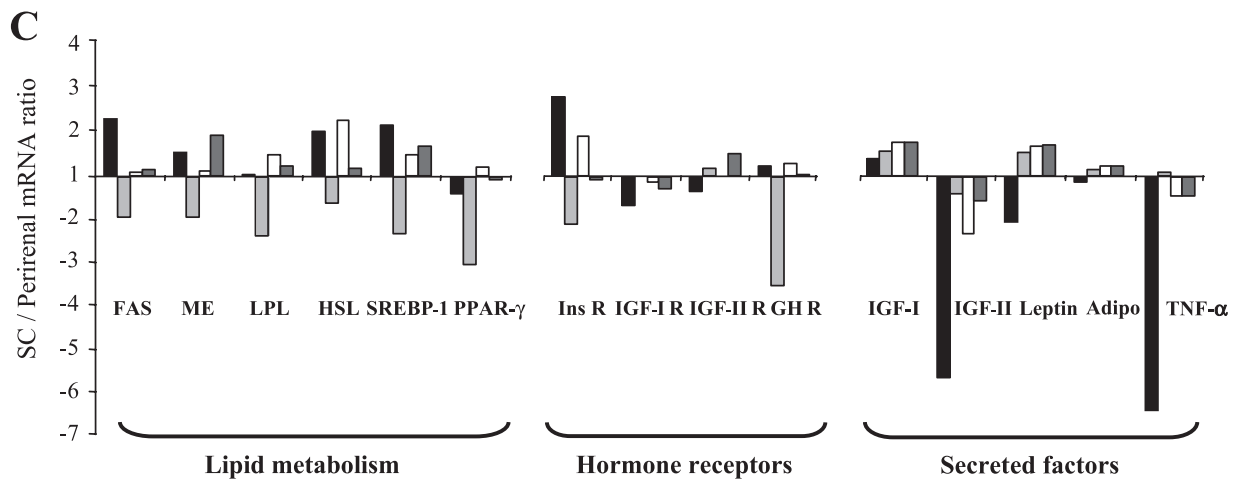

precursors into fatty acids (52) and depressed activities of rate-limiting enzymes in fat synthesis $(6,34,41)$ have been reported in bovine IM adipocytes or porcine interfascicular muscle fat strands compared with SC adipose tissue. Others have found similar lipogenic enzyme activities (40) or even greater FAS activity (52) in bovine IM vs. SC adipose tissues, probably as a result of a particular propensity of muscle to accumulate lipids and marbling in some breeds. Finally, the lower rate of insulin-stimulated glucose incorporation into fatty acids found in IM fat cells compared with other adipocytes is consistent with the observed site-related differences in mRNA levels of insulin receptor.

Our study also provides new insights into lipid catabolism in IM adipocytes during growth, showing that, despite their location in close vicinity to contracting oxidative myofibers, IM adipocytes displayed markedly lower mRNA levels of
HSL, which catalyzes the rate-limiting step in adipocyte lipolysis and basal and catecholamine-induced lipolytic rates compared with other adipocytes. It seems reasonable, therefore, to speculate that lipogenesis and lipolysis are coordinated pathways in porcine adipocytes, as suggested in rat adipocytes (17). The lower magnitude of the differences between sites for basal lipolytic rate than for HSL mRNA levels might be related to the fact that HSL enzyme activity is primarily regulated by reversible phosphorylation (27). Despite low metabolic capacities in IM adipocytes, the age-related increase in the imbalance between in situ lipogenesis and lipolysis in favor of fatty acid synthesis may contribute to the observed enlargement of IM adipocytes and lipid deposition in whole muscle during the growth period studied. An increase in fatty acid transport within IM adipocytes with advancing age is also possible. Last, late 


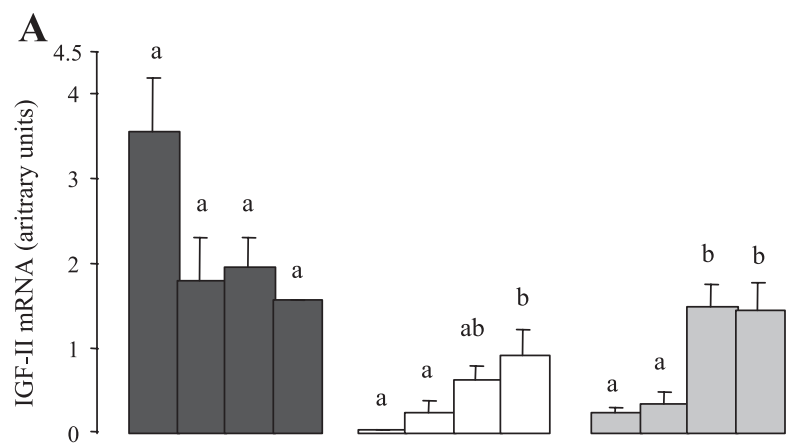

B
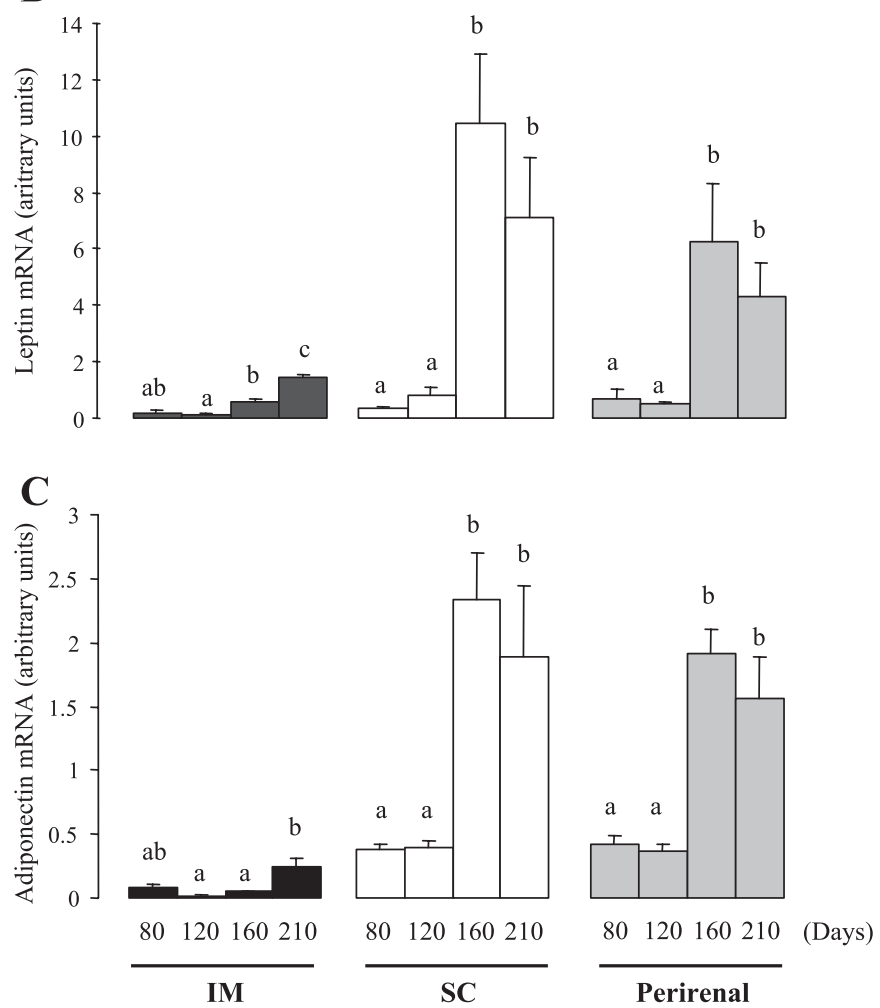

Fig. 6. Age-related changes in $\operatorname{IGF}-\mathrm{II}(A)$, leptin $(B)$, and adiponectin $(C)$ mRNA levels in IM, SC, and perirenal isolated adipocytes. mRNA levels were determined by real-time RT-PCR at indicated ages (days) and quantified as described in MATERIALS AND METHODS. Values are means $\pm \mathrm{SE} ; n=8$ per age group for SC and perirenal adipocytes, $n=4$ for IM adipocytes. ${ }^{\text {abc Within each }}$ site, means with different letters are different $(P<0.05)$.

adipocyte hyperplasia (33) could possibly contribute to the age-related increase in muscle lipid content.

To our knowledge, the present study is the first to show that IM adipocytes, like SC and perirenal fat cells, expressed a variety of genes that encode proteins involved in the regulation of lipid metabolism and/or cell development. With the exception of TNF- $\alpha$, the expressions of genes coding for various hormonal receptors and secreted factors differ between IM and nonmuscular adipocytes. Interestingly, the magnitude of the differences was lower than that observed for lipid-related metabolic genes. Concerning $\mathrm{TNF}-\alpha$, which plays a major role in inflammatory response, apoptosis, and adipocyte metabolism $(50,59)$, mRNA expression was similar in $\mathrm{SC}$ and perirenal adipocytes, as reported in humans $(13,43)$, but also between IM and other adipocytes. The current finding of an age-related increase in leptin mRNA levels that paralleled changes in average adipocyte diameters and lipid mass in the three sites is consistent with leptin's physiological role as a signal of fat mass. For adiponectin, the adipocyte-secreted plasma protein known to regulate glucose and lipid metabolism (20), mRNA levels also increased with cell size in the three sites. This observation suggests a possible relationship between cell size and adiponectin expression in physiological conditions. The rank order $\mathrm{SC}>$ perirenal $>$ IM observed for both leptin and IGF-I mRNA expressions in the current study is in accord with studies reporting higher leptin mRNA levels in SC than in visceral adipose tissues in humans $(39,42,54)$ and with studies showing a correlation between leptin and IGF-I expression in the various regions of rat adipose tissue (57). The finding of the highest IGF-II mRNA level in IM adipocytes associated with the observation that IGF-II expression did not change with age in IM adipocytes but increased in SC and perirenal adipocytes further emphasizes the differences between IM adipocytes and nonmuscular adipocytes. In the current study, the evidence of IGF receptor mRNA in IM adipocytes supports the possibility of an autocrine/paracrine effect of IGF-II in adipocytes. However, the role of IGF-II in adipocytes is poorly documented compared with its effects on muscle fiber differentiation and growth $(29,45)$. Due to the close vicinity of myofibers, one can speculate that IM adipocytes produce IGF-II, which may interact with muscle cells through local paracrine effects. Observations in pigs exhibiting a mutation in the IGF-II gene (55) support a possible action of IGF-II on the regulation of both muscle mass and adiposity. Indeed, the mutation that is associated with a higher expression of IGF-II in muscle leads to decreased adiposity and a higher lean mass in the body. Nevertheless, it remains to be determined whether the high expression of IGF-II in IM adipocytes relative to fat cells isolated from other locations may favor myofiber differentiation and growth and/or could directly act on IM adipocyte features through autocrine action.

Altogether, specific metabolic and secretory capacities of IM adipocytes could be due to the smaller size of IM adipocytes compared with adipocytes of other fat depots at a given age. Indeed, low lipogenic and lipolytic capacities and reduced expressions of various proteins involved in lipid metabolism or secretory function have been previously evidenced in small compared with large adipocytes isolated from a given location in pigs (15), rats (17), mice (3, 4), and humans (49). The integrin-ERKs signaling pathway has been recently suggested as one of the intracellular mechanisms responsible for the adaptation of adipose functions to cell size (17). It is interesting to note that ERKs action is known to result in both transcriptional [e.g., SREBP activation, (30)] and posttranscriptional [e.g., HSL phosphorylation, (24)] effects, which might underline the observed site-related differences in both lipogenic (FAS, ME) and lipolytic (HSL) gene expressions or activities. One could also argue that the small size of IM adipocytes reflects a lower physiological maturity compared with fat cells isolated from SC and perirenal locations at a given age. Indeed, IM adipose tissue is known to be the latest-developing adipose tissue in pigs $(26,33)$. In support of this hypothesis, we currently observed no change in lipogenic activities and a continuous increase in leptin mRNA levels in IM adipocytes with advancing age, whereas the same targets decreased or reached a plateau, respectively, in SC and perirenal fat cells at 
the latest stage of growth studied. However, it seems unlikely that differences in cell size and degree of maturity would be responsible for all of the observed differences between adipocytes of different sites. For instance, commensurate differences in adipocyte features were maintained when IM adipocytes isolated from 210-day-old pigs were examined compared with SC adipocytes isolated from 80-day-old pigs, despite similar average cell diameter. Therefore, it is likely that, in addition to systemic factors, local region-specific regulators may affect adipocyte biology. Insulin signaling $(3,42)$ or tissue parasympathetic innervation (31) may be involved. Moreover, different cocultured systems experiments have evidenced paracrine cross talk between muscle cells and adipocytes (10, 11). Last, it can be hypothesized that the specific function of IM adipocytes compared with that of SC and perirenal adipocytes may result, at least partly, from the competition between IM adipocytes and muscle fibers for nutrient uptake. Indeed, recent studies have underlined two vascular circuits for fatty acid supply in muscle, one (nutritive) supplying the myocytes, the other (nonnutritive) supplying the connective tissue and the closely associated IM adipocytes $(8,9)$.

In conclusion, this study has provided new insights into IM adipocyte features, showing that IM fat is not just an ectopic extension of another adipose tissue location. Although metabolic activities were very low in IM adipocytes relative to those in SC and perirenal sites, we have clearly shown that IM adipocytes displayed substantial modifications in lipid metabolism during growth. Furthermore, IM adipocytes expressed various adipokines at levels comparable to those observed in other cells. Because muscle type-associated differences in fatty acid uptake, esterification, and oxidation abilities have been well described at the whole tissue level (14), one cannot exclude the possibility that IM adipocytes of a white muscle may exhibit different features than those evidenced here on adipocytes isolated from a red muscle. However, it is likely that regional differences in adipocyte functions between muscle and nonmuscular adipose tissues are greater than those that might be observed between adipocytes from different muscle types. Altogether, further studies will be required to elucidate the role of IM adipocyte-specific features in normal muscle physiology and/or in metabolic disorder occurrence.

\section{ACKNOWLEDGMENTS}

We thank F. Pontrucher and C. Tréfeu for expert technical assistance.

\section{GRANTS}

D. Gardan was supported by a grant from the French Ministry of Education and Research.

\section{REFERENCES}

1. Anderson DB, Kauffman RG, and Kastenschmidt LL. Lipogenic enzyme activities and cellularity of porcine adipose tissue from various anatomical locations. J Lipid Res 13: 593-599, 1972.

2. Bazin R and Ferre P. Assays of lipogenic enzymes. Methods Mol Biol 155: 121-127, 2001.

3. Bluher M, Patti ME, Gesta S, Kahn BB, and Kahn CR. Intrinsic heterogeneity in adipose tissue of fat-specific insulin receptor knock-out mice is associated with differences in patterns of gene expression. $J$ Biol Chem 279: 31891-31901, 2004.

4. Bluher M, Wilson-Fritch L, Leszyk J, Laustsen PG, Corvera S, and Kahn CR. Role of insulin action and cell size on protein expression patterns in adipocytes. J Biol Chem 279: 31902-31909, 2004.
5. Budd TJ, Atkinson JL, Buttery PJ, Salter AM, and Wiseman J. Effect of insulin and isoproterenol on lipid metabolism in porcine adipose tissue from different depots. Comp Biochem Physiol Pharmacol Toxicol Endocrinol 108: 137-143, 1994.

6. Chakrabarty K and Romans JR. Lipogenesis in the adipose cells of the bovine (Bos taurus) as related to their intramuscular fat content. Comp Biochem Physiol B 41: 603-615, 1972.

7. Chomczynski $\mathbf{P}$ and Sacchi N. Single-step method of RNA isolation by acid guanidinium thiocyanate-phenol-chloroform extraction. Anal Biochem 162: 156-159, 1987.

8. Clerk LH, Smith ME, Rattigan S, and Clark MG. Increased chylomicron triglyceride hydrolysis by connective tissue flow in perfused rat hindlimb. Implications for lipid storage. J Lipid Res 41: 329-335, 2000.

9. Clerk LH, Smith ME, Rattigan S, and Clark MG. Nonnutritive flow impairs uptake of fatty acid by white muscles of the perfused rat hindlimb. Am J Physiol Endocrinol Metab 284: E611-E617, 2003.

10. Dietze D, Koenen M, Rohrig K, Horikoshi H, Hauner H, and Eckel J. Impairment of insulin signaling in human skeletal muscle cells by coculture with human adipocytes. Diabetes 51: 2369-2376, 2002.

11. Dietze D, Ramrath S, Ritzeler O, Tennagels N, Hauner H, and Eckel J. Inhibitor kappaB kinase is involved in the paracrine crosstalk between human fat and muscle cells. Int J Obes Relat Metab Disord 28: 985-992, 2004.

12. Dole VP and Meinertz H. Microdetermination of long-chain fatty acids in plasma and tissues. J Biol Chem 235: 2595-2599, 1960.

13. Dusserre E, Moulin P, and Vidal H. Differences in mRNA expression of the proteins secreted by the adipocytes in human subcutaneous and visceral adipose tissues. Biochim Biophys Acta 1500: 88-96, 2000.

14. Dyck DJ, Peters SJ, Glatz J, Gorski J, Keizer H, Kiens B, Liu S, Richter EA, Spriet LL, van der Vusse GJ, and Bonen A. Functional differences in lipid metabolism in resting skeletal muscle of various fiber types. Am J Physiol Endocrinol Metab 272: E340-E351, 1997.

15. Etherton TD, Aberle ED, Thompson EH, and Allen CE. Effects of cell size and animal age on glucose metabolism in pig adipose tissue. $J$ Lipid Res 22: 72-80, 1981.

16. Etherton TD and Chung CS. Preparation, characterization, and insulin sensitivity of isolated swine adipocytes: comparison with adipose tissue slices. J Lipid Res 22: 1053-1059, 1981.

17. Farnier C, Krief S, Blache M, Diot-Dupuy F, Mory G, Ferre P, and Bazin R. Adipocyte functions are modulated by cell size change: potential involvement of an integrin/ERK signalling pathway. Int $J$ Obes Relat Metab Disord 27: 1178-1186, 2003.

18. Folch J, Lees M, and Sloane Stanley GH. A simple method for the isolation and purification of total lipids from animal tissues. $J$ Biol Chem 226: 497-509, 1957

19. Foster CM, Hale PM, Jing HW, and Schwartz J. Effects of human growth hormone on insulin-stimulated glucose metabolism in 3T3-F442A adipocytes. Endocrinology 123: 1082-1088, 1988.

20. Giorgino F, Laviola L, and Eriksson JW. Regional differences of insulin action in adipose tissue: insights from in vivo and in vitro studies. Acta Physiol Scand 183: 13-30, 2005.

21. Gondret $\mathbf{F}$ and Lebret B. Feeding intensity and dietary protein level affect adipocyte cellularity and lipogenic capacity of muscle homogenates in growing pigs, without modification of the expression of sterol regulatory element binding protein. J Anim Sci 80: 3184-3193, 2002.

22. Gondret F, Mourot J, and Bonneau M. Comparison of intramuscular adipose tissue cellularity in muscles differing in their lipid content and fiber type composition during rabbit growth. Livest Prod Sci 54: 1-10, 1998.

23. Goodpaster BH and Wolf D. Skeletal muscle lipid accumulation in obesity, insulin resistance, and type 2 diabetes. Pediatr Diabetes 5: 219-226, 2004.

24. Greenberg AS, Shen WJ, Muliro K, Patel S, Souza SC, Roth RA, and Kraemer FB. Stimulation of lipolysis and hormone-sensitive lipase via the extracellular signal-regulated kinase pathway. J Biol Chem 276: 45456-45461, 2001.

25. Handel SE and Stickland NC. The growth and differentiation of porcine skeletal muscle fibre types and the influence of birthweight. J Anat 152: 107-119, 1987.

26. Hauser N, Mourot J, De Clercq L, Genart C, and Remacle C. The cellularity of developing adipose tissues in Pietrain and Meishan pigs. Reprod Nutr Dev 37: 617-625, 1997.

27. Holm C. Molecular mechanisms regulating hormone-sensitive lipase and lipolysis. Biochem Soc Trans 31: 1120-1124, 2003. 
28. Hood RL and Allen CE. Cellularity of bovine adipose tissue. J Lipid Res 14: 605-610, 1973.

29. Kokta TA, Dodson MV, Gertler A, and Hill RA. Intercellular signaling between adipose tissue and muscle tissue. Domest Anim Endocrinol 27: 303-331, 2004.

30. Kotzka J, Muller-Wieland D, Roth G, Kremer L, Munck M, Schurmann S, Knebel B, and Krone W. Sterol regulatory element binding proteins (SREBP)-1a and SREBP-2 are linked to the MAP-kinase cascade. J Lipid Res 41: 99-108, 2000.

31. Kreier F, Fliers E, Voshol PJ, Van Eden CG, Havekes LM, Kalsbeek A, Van Heijningen CL, Sluiter AA, Mettenleiter TC, Romijn JA, Sauerwein HP, and Buijs RM. Selective parasympathetic innervation of subcutaneous and intra-abdominal fat-functional implications. J Clin Invest 110: 1243-1250, 2002.

32. Lafontan M and Berlan M. Do regional differences in adipocyte biology provide new pathophysiological insights? Trends Pharmacol Sci 24: 276-283, 2003.

33. Lee YB and Kauffman RG. Cellular and enzymatic changes with animal growth in porcine intramuscular adipose tissue. J Anim Sci 38: 532-537, 1974.

34. Lee YB and Kauffman RG. Cellularity and lipogenic enzyme activities of porcine intramuscular adipose tissue. J Anim Sci 38: 538-544, 1974.

35. Louveau I, Chaudhuri S, and Etherton TD. An improved method for isolating RNA from porcine adipose tissue. Anal Biochem 196: 308-310, 1991.

36. Louveau I and Gondret F. GH and insulin affect fatty acid synthase activity in isolated porcine adipocytes in culture without any modifications of sterol regulatory element binding protein-1 expression. $J$ Endocrinol 181: 271-280, 2004.

37. Lundgren M, Buren J, Ruge T, Myrnas T, and Eriksson JW. Glucocorticoids down-regulate glucose uptake capacity and insulin-signaling proteins in omental but not subcutaneous human adipocytes. $J$ Clin Endocrinol Metab 89: 2989-2997, 2004.

38. Machann J, Haring H, Schick F, and Stumvoll M. Intramyocellular lipids and insulin resistance. Diabetes Obes Metab 6: 239-248, 2004.

39. Masuzaki H, Ogawa Y, Isse N, Satoh N, Okazaki T, Shigemoto M, Mori K, Tamura N, Hosoda K, Yoshimasa Y, Jingami H, Kawada T, and Nakao K. Human obese gene expression. Adipocyte-specific expression and regional differences in the adipose tissue. Diabetes 44: 855-858, 1995.

40. May SG, Burney NS, Wilson JJ, Savell JW, Herring AD, Lunt DK, Baker JF, Sanders JO, and Smith SB. Lipogenic activity of intramuscular and subcutaneous adipose tissues from steers produced by different generations of angus sires. J Anim Sci 73: 1310-1317, 1995.

41. May SG, Savell JW, Lunt DK, Wilson JJ, Laurenz JC, and Smith SB. Evidence for preadipocyte proliferation during culture of subcutaneous and intramuscular adipose tissues from Angus and Wagyu crossbred steers. J Anim Sci 72: 3110-3117, 1994.

42. Montague CT, Prins JB, Sanders L, Digby JE, and O'Rahilly S. Depot- and sex-specific differences in human leptin mRNA expression: implications for the control of regional fat distribution. Diabetes 46: 342-347, 1997.

43. Montague CT, Prins JB, Sanders L, Zhang J, Sewter CP, Digby J, Byrne CD, and O'Rahilly S. Depot-related gene expression in human subcutaneous and omental adipocytes. Diabetes 47: 1384-1391, 1998.

44. Mourot J, Kouba M, and Peiniau P. Comparative study of in vitro lipogenesis in various adipose tissues in the growing domestic pig (Sus domesticus). Comp Biochem Physiol B Biochem Mol Biol 111: 379-384, 1995.

45. Oksbjerg N, Gondret F, and Vestergaard M. Basic principles of muscle development and growth in meat-producing mammals as affected by the insulin-like growth factor (IGF) system. Domest Anim Endocrinol 27: 219-240, 2004.

46. Patel MS, Owen OE, Goldman LI, and Hanson RW. Fatty acid synthesis by human adipose tissue. Metabolism 24: 161-173, 1975.

47. Pfaffl MW. A new mathematical model for relative quantification in real-time RT-PCR. Nucleic Acids Res 29: 2002-2007, 2001.

48. Poulos $\mathbf{S}$ and Hausman G. Intramuscular adipocytes-potential to prevent lipotoxicity in skeletal muscle. Adipocytes 1: 79-94, 2005.

49. Reynisdottir S, Dauzats M, Thorne A, and Langin D. Comparison of hormone-sensitive lipase activity in visceral and subcutaneous human adipose tissue. J Clin Endocrinol Metab 82: 4162-4166, 1997.

50. Sethi JK and Hotamisligil GS. The role of TNF alpha in adipocyte metabolism. Semin Cell Dev Biol 10: 19-29, 1999.

51. Smekal G, von Duvillard SP, Pokan R, Tschan H, Baron R, Hofmann P, Wonisch M, and Bachl N. Effect of endurance training on muscle fat metabolism during prolonged exercise: agreements and disagreements. Nutrition 19: 891-900, 2003.

52. Smith SB and Crouse JD. Relative contributions of acetate, lactate and glucose to lipogenesis in bovine intramuscular and subcutaneous adipose tissue. J Nutr 114: 792-800, 1984.

53. Valsta LM, Tapanainen H, and Männisto S. Meat fats in nutrition. Meat Sci 70: 525-530, 2005.

54. van Harmelen V, Reynisdottir S, Eriksson P, Thorne A, Hoffstedt J, Lonnqvist F, and Arner P. Leptin secretion from subcutaneous and visceral adipose tissue in women. Diabetes 47: 913-917, 1998.

55. Van Laere AS, Nguyen M, Braunschweig M, Nezer C, Collette C, Moreau L, Archibald AL, Haley CS, Buys N, Tally M, Andersson G, Georges M, and Andersson L. A regulatory mutation in IGF2 causes a major QTL effect on muscle growth in the pig. Nature 425: 832-836, 2003.

56. van Loon LJ. Use of intramuscular triacylglycerol as a substrate source during exercise in humans. J Appl Physiol 97: 1170-1187, 2004.

57. Villafuerte BC, Fine JB, Bai Y, Zhao W, Fleming S, and DiGirolamo M. Expressions of leptin and insulin-like growth factor-I are highly correlated and region-specific in adipose tissue of growing rats. Obes Res 8: 646-655, 2000.

58. Wajchenberg BL. Subcutaneous and visceral adipose tissue: their relation to the metabolic syndrome. Endocr Rev 21: 697-738, 2000.

59. Warne JP. Tumour necrosis factor alpha: a key regulator of adipose tissue mass. J Endocrinol 177: 351-355, 2003. 